\title{
PARENT EDUCATION PROGRAM MENGGUNAKAN VIDEO ANIMASI DENTAL HEALTH EDUCATION (DHE) BAGI ANAK DOWN SYNDROME DALAM PENCEGAHAN KARIES GIGI SELAMA PANDEMI COVID
}

\author{
Renie Kumala Dewi ${ }^{1 *}$, Beta Widya Oktiani ${ }^{2}$, Hilyatul Auliya ${ }^{3}$, I Wayan Arya Krishnawan \\ Firdaus $^{4}$, Ika Kusuma Wardani ${ }^{5}$, Irham Taufiqurrahman ${ }^{6}$ \\ ${ }^{1}$ Departemen Ilmu Kedokteran Gigi Anak, Fakultas Kedokteran Gigi, Universitas Lambung \\ Mangkurat, Banjarmasin. \\ ${ }^{2}$ Departemen Periodonsia, Fakultas Kedokteran Gigi, Universitas Lambung Mangkurat, \\ Banjarmasin. \\ ${ }^{3}$ Co-assistance Fakultas Kedokteran Gigi, Universitas Lambung Mangkurat, Banjarmasin. \\ ${ }^{4}$ Departemen Ilmu Biologi Oral, Fakultas Kedokteran Gigi, Universitas Lambung Mangkurat, \\ Banjarmasin. \\ ${ }^{5}$ Departemen Ilmu Kedokteran Gigi Masyarakat, Universitas Lambung Mangkurat, Banjarmasin \\ ${ }^{6}$ Departemen Ilmu Bedah Mulut, Fakultas Kedokteran Gigi, Universitas Lambung Mangkurat, \\ Banjarmasin \\ Email: renie.dewi@ulm.ac.id ${ }^{1 *}$,drgbetawidyaoktiani@gmail.com², auliyaahilya@ gmail.com ${ }^{3}$, \\ iwayan.firdaus@ulm.ac.id ${ }^{4}$, ika.wardani@ulm.ac.id ${ }^{5}$, irham.taufiqurrahman@ulm.ac.id ${ }^{6}$ \\ *Coresponding author: Renie Kumala Dewi. J1. Veteran Sungai Bilu No.128, Melayu, Kec. \\ Banjarmasin Tengah, Kota Banjarmasin, Kalimantan Selatan 70122. renie.dewi@ulm.ac.id. Telp. \\ 081230000769
}

\begin{abstract}
Abstrak
Latar belakang. Anak dengan down syndrome adalah anak yang mengalami keterlambatan perkembangan mental. Keadaan rongga mulut pada anak down syndrome adalah penyakit periodontal dan karies gigi. Banjarmasin dikenal dengan kota seribu sungai yang merupakan wilayah lahan basah. Kandungan air lahan basah bersifat asam dan mengandung bakteri Streptococcus penyebab karies. Kebiasaan menggunakan air lahan basah dalam kehidupan sehari-hari dapat meningkatkan prevalensi karies gigi. Tindakan yang dapat dilakukan selama pandemi covid dengan memberikan edukasi video animasi interaktif Dental Helath Education (DHE) sebagai parent education program karena orangtua merupakan pusat edukasi pertama dalam mendidik anak. Tujuan. Mengetahui pengaruh parent education program menggunakan video DHE bagi anak terhadap pencegahan karies gigi selama pandemi covid. Metode. Penyuluhan menggunakan video animasi DHE bagi anak down syndrome dalam pencegahan karies gigi selama pandemi covid. kegiatan pengabdian bekerjasama dengan yayasan PIK POTADS (Persatuan Orang Tua dan Anak Down Syndrome) wilayah Kalimantan Selatan yang dihadiri oleh orang tua dengan anak down syndrome sebanyak 48 peserta yang dilaksanakan secara online, sebagai penguatan kembali mengenai penyuluhan, para orang tua diminta untuk mengisi kuesioner setelah pemberian video penyuluhan tersebut, Hasil. Didapatkan kategori baik terhadap parent education menggunakan video animasi DHE terhadap kesehatan gigi dan mulut dalam pencegahan karies gigi selama pandemic covid-19.
\end{abstract}

Kata kunci. Parent education; Video animasi; Dental Health Education (DHE); Down syndrome

$$
\text { Kesehatan } 340
$$




\section{PENDAHULUAN}

Down syndrome merupakan kelainan kongenital yang ditandai dengan jumlah kromosom yang abnormal yaitu kromosom 21 berjumlah 3 buah sehingga jumlah seluruh kromosom mencapai 47 buah, sedangkan pada manusia normal jumlah kromosom sel mengandung 23 pasang kromosom. Kelainan kromosom ini menyebabkan keterlambatan perkembangan otak (Hafsah, 2020).

Gambaran klinis secara umum anak down syndrome secara umum mempunyai tanda tanda spesifik yang sama walaupun pada ras yang berbeda. Tanda-tanda tersebut adalah sebagai berikut: Hipotonia otot-otot termasuk ototorofasial /mulut. Adanya retardasi mental, volume otak lebih kecil dari normal. Wajah: brakisefali dengan belakang kepala yang datar, mikrosefali, palatum yang pendek, hidung kecil dengan pangkal hidung yang rata, dan adanya lipatan epikantus sebelah dalam. Mata: adanya bintik Brushfield disertai hipoplasia iris perifer, miopia (70\%), nistagmus (35\%), strabismus (45\%), sumbatan duktus lakrimalis (20\%), katarak (30-60\%). Telinga: kecil, lipatanyang berlebihan pada sudut atas heliks, tuli konduktif, campuran atau sensorineural (66\%), pengumpulan cairan di telinga tengah (60-80\%). Extremitas; kaki menunjukkan sandal gap dan tangan menunjukan simian crease. Tangan metakarpal dan falang relatif lebih pendek, jari ke lima mengalami hioplasia dari midfalang (60\%), klinodaktili $(50 \%)$, garis Simian (45Jarak yang lebar antara jari pertama dan kedua, garis plantar antara jari pertama dan kedua (Soewondono, 2019).

Menurut World Health Organization (WHO) tahun 2011, sebanyak 7-10\% anak di dunia memiliki disabilitas. Data lain dari Badan Pusat Statistik Nasional tahun 2007 menyebutkan bahwa sekitar $10 \%$ atau 8,3 juta jiwa anak di Indonesia memiliki disabilitas. Penderita down syndrome saat ini berjumlah 8 juta di dunia. Setiap tahun diperkirakan terdapat 3.000 hingga 5.000 anak terlahir dengan down syndrome. Data dari RISKESDAS 2013 menyatakan bahwa terdapat 300.000 kasus anak yang mengalami down syndrome di Indonesia (Hafsah, 2020; Chrisly, 2017).

Anak down syndrome mempunyai keterlambatan dan keterbatasan dalam semua perkembangan sehingga mereka mengalami kesulitan untuk merawat diri sendiri salah satunya menjaga Kesehatan gigi dan mulutnya. Keterbelakangan tersebut menjadikan penderita ini tidak bisa menjaga kesehatan diri sendiri.9 Kondisi rongga mulut para penderita down syndrome bisanya mulut selalu terbuka, lidah maupun bibir terbentuk celah dan fissure. Pembentukan fissure pada lidah dapat menjadi berat dan merupakan faktor kontribusi pada terjadinya halitosis. Palatum penderita down syndrome terlihat sempit dengan cekungan yang tajam, keadaan ini mempengaruhi fungsi bicara dan mastikasi (Chrisly, 2017).

Masalah kesehatan gigi dan mulut pada anak down syndrome adalah gingivitis, periodontitis dan karies gigi yang cepat, sedangkan pada masa pandemi Covid tindakan kedokteran gigi yang dapat dilakukan hanya yang bersifat darurat seperti nyeri yang tidak tertahan, gusi yang bengkak, perdarahan yang tidak terkontrol dan trauma pada gigi dan tulang wajah yang berpotensi mengganggu jalan nafas, sebagian besar orang tua yang tinggal di lahan basah sering memiliki kebiasaan menggunakan air lahan basah dalam kehidupan sehari-hari seperti berkumur ketika menggosok gigi. Lahan basah merupakan rawa dengan tingkat keasaman air yaitu $\mathrm{pH}$ 3,5 - 4,5. Kandungan air lahan basah di Kalimantan Selatan ditemukan bakteri yang dapat menyebabkan karies salah satunya Streptococcus, sp (Ozkan, 2015; Monica, 2015).

Permasalahan kesehatan gigi dan mulut pada masa pandemi Covid tidak dapat ditangani, sehingga diperlukan media edukasi terutama kepada anak tunagrahita mengenai Dental Health Education (DHE) untuk membantu menjaga kesehatan rongga mulutnya selama masa pandemi Covid (Ozkan, 2015; KEMENKES; 2020; Andriyani, 2017).

Mendengarkan saja tidak sama tingkat Kesehatan $\quad 341$ 
pemahamannya dibandingkan dengan melihat dan mendengarkan, sehingga media edukasi yang baik untuk anak down syndrome adalah media video interaktif. Media video yang interaktif, dimasukkan langkah-langkah menjaga kesehatan gigi dan mulut sehingga anak dapat mengamati dan dapat dipraktekkan ketika anak sudah memahami kegiatan yang ada di dalam video tersebut (Ozcan, 2014; Novitasari, 2015).

Media video juga bisa dimanfaatkan untuk hampir semua topik, model-model pembelajaran, dan setiap ranah kognitif, afektif, dan psikomotorik. Secara kognitif dengan melihat video dapat memperkuat pemahaman orang tua terhadap materi ajar sebelum ataupun sesudah membaca sebuah materi edukasi. Pada ranah afektif, video dapat memperkuat orang tua dalam merasakan unsur emosi dan penyikapan dari pembelajaran yang efektif. Pada ranah psikomotorik, video memiliki keunggulan dalam memperlihatkan bagaimana sesuatu bekerja, video pembelajaran yang merekam kegiatan motorik/ gerak dapat memberikan kesempatan pada orang tua untuk mengamati dan mengevaluasi kembali kegiatan tersebut. Berdasarkan hal tersebut pada penelitian ini dilakukan media edukasi dengan menggunakan video (Kantohe dkk, 2016).

Anak down sidrome memiliki tingkat kecerdasan rendah sehingga untuk mempelajari tugas perkembangan memerlukan bantuan atau layanan secara khusus, terutama di dalam kebutuhan program pendidikan dan bimbingan. Orangtua mempunyai peran yang sangat penting dalam perawatan gigi anakanaknya. Upaya meningkatkan bina diri Kesehatan gigi dan mulut pada anak down syndrome dapat dilakukan dengan pemberian edukasi seperti metode demonstrasi, modeling dan pelatihan, karena keluarga merupakan pusat edukasi yang utama, dalam keluarga itulah kepribadian anak terbentuk, Orangtua mempunyai peran yang sangat penting dalam perawatan gigi anak-anaknya, dengan peran yang dilakukan orang tua meliputi memberi contoh perawatan gigi, memotivasi merawat gigi, mengawasi perawatan gigi, dan membawa anak ke pelayanan kesehatan gigi jika anak sakit gigi. Dalam hal ini, peran keluarga sangat diperlukan sebagai stimulus dan dukungan orang-orang terdekat terutama orang tua sangat penting untuk mengoptimalkan kemampuan anak down syndrome dalam hal mengembangkan personal hygiene salah satunya menjaga Kesehatan dan kebersihan gigi dan mulut (Sujarwati, 2019)

Berdasarkan uraian permasalahan yang telah disampaikan di atas maka perlu dikembangkan pembuatan media video edukasi dalam menjaga kebersihan gigi dan mulut (oral hygiene) anak tunagrahita sebagai parent education program dan pengaruh peran orang tua dalam menjaga kesehatan gigi dan mulut anak down syndrome dimasa pandemic covid 19.

\section{METODE}

Prosedur PKM ini dilakukan bekerjasama dengan Yayasan Komunitas Pusat Informasi dan Komunikasi Persatuan Orang Tua dengan Anak Down Syndrome (PIK POTADS) Kalimantan Selatan dan tim PKM FKG ULM yang terdiri dari beberapa dokter gigi spesialis yang berbeda. Pemilihan lokasi pengabdian ini dipilih dengan pertimbangan bahwa POTADS merupakan komunitas orang tua yang memiliki anak dengan down syndrome. POTADS Kalsel memiliki 85 anggota yang terdiri dari orang tua anak dengan down syndrome dari berbagai usia yang tersebar di beberapa kota di Kalimantan Selatan.

Tujuan utama dari kegiatan ini adalah memberdayakan orang tua anak down syndrome agar selalu bersemangat untuk membantu tumbuh kembang anak dan bina diri salah satunya dengan menjaga Kesehatan gigi dan mulut terutama disaat pandemic covid, karena anak dengan down syndrome memiliki hak yang sama dengan anakanak lainnya. 
Berdasarkan identifikasi masalah tersebut diatas, tim PKM FKG ULM melakukan metode dan strategi dalam mengatasi permasalahan tersebut melalui tahapan yang dilakukan untuk pelaksanaan program PKM-CSR dengan pendekatan yang telah disepakati bersama untuk menyelesaikan masalah tersebut, dimulai dengan :

(1). Kegiatan ini dimulai dengan menghubungi ketua Yayasan PIK POTADS Kalsel dan menjelaskan maksud dan tujuan penyuluhan yang akan dilakukan oleh Tim PKM. Penyuluhan Kesehatan gigi dan mulut pada orang tua anak down syndrome dilakukan dengan menggunakan media video Dental Health Education (DHE). (2) Video penyuluhan bagi orang tua anak down syndrome dibuat oleh Tim pelaksana PKM yang berisi video animasi bagi anak berkebutuhan khusus dengan modifikasi metode Makaton yaitu berupa penambahan lagu anak-anak dalam bentuk simbol mengenai pemilihan dan penggunaan sikat gigi dan pasta gigi yang benar, cara menggosok gigi yang baik dan benar, posisi orang tua dan anak dalam menggosok gigi pada anak berkebutuhan khusus, jenis makanan dan minuman yang baik dan buruk untuk gigi, pemilihan air kumur yang benar setelah menggosok gigi pada anak yang tinggal di lahan basah, penggunaan pasta gigi yang mengandung antiseptic dan fluor, dan cara menjaga kesehatan gigi dan mulut anak selama pandemi Covid. (3) Penyuluhan DHE dilakukan setelah membuat jadwal bersama pihak POTADS Kalsel yang dilakukan secara daring dalam bentuk webinar penyuluhan Kesehatan gigi dan mulut yang dihadiri sebanyak 38 orang tua bersama anaknya yang down syndrome. Pelaksanaan dilakukan secara online dikarenakan anak dengan down syndrome memiliki Kesehatan umum yang sangat rentan terhadap tertularnya suatu penyakit dari pada anak normal lainnya, selain itu dimasa pandemic covid mengharuskan membatasi kegiatan yang bersifat kerumunan. (4) Penyuluhan dilakukan dengan memberikan materi tentang menjaga Kesehatan gigi dan mulut anak down syndrome, memberikan contoh demo menggosok gigi yang benar dengan menggunakan pantom/model gigi kemudian dilanjutkan dengan sesi diskusi tanya jawab dari para orang tua kepada tim PKM. (4) Menunjukkan video Dental Health Education (DHE) sebagai pemantapan orang tua tentang Kesehatan gigi dan mulut anak down syndrome yang tinggal di lahan basah selama pandemic Covid. (5) Pembagian pasta gigi yang mengandung fluoride dan Chlorhexidine $0.012 \%$ melalui undian yang diundi secara acak dan diberikan kepada orang tua yang beruntung.

Sebagai evaluasi dan monitoring terhadap kegiatan pengabdian parent education program ini, orang tua diberikan beberapa pertanyaan berupa kuesioner tentang pengetahuan menjaga kesehatan gigi dan mulut anak down syndrome melalui google form yang dibagikan melalui link dan diisi pada saat sesudah diberikan materi dan menonton video Dental Health Education (DHE) anak down sidrome yang tinggal di lahan basah dalam pencegahan karies gigi selama pandemic covid. Disamping itu video tentang DHE yang dibuat oleh Tim PKM FKG ULM diserahkan kepada ketua POTADS Kalsel untuk disebarkan ke anggota selaku orang tua anak down syndrome agar dapat dimanfaatkan sebagai media pembelajaran untuk menjaga kesehatan dan kebersihan rongga mulut anak sehari-hari.

\section{HASIL DAN PEMBAHASAN}

\section{Sub bab 1}

Pelaksanaan kegiatan pengabdian masyarakat ini dilaksanakan melalui webinar online yang bekerjasama antara Tim FKG ULM dengan Yayasan Komunitas Pusat Informasi dan Komunikasi Persatuan Orang Tua dengan Anak Down Syndrome (PIK POTADS) Kalimantan Selatan bersama tim PKM FKG ULM yang dilaksanakan pada bulan September 2021 telah berjalan dengan baik dan lancar, penyulahan dilaksanakan dengan sasaran orang tua yang memiliki anak down syndrome yang tinggal di lahan basah yakni di provinsi Kalimantan Selatan selaku anggota dari POTADS Kalsel dengan materi 
pengetahuan tentang Dental Health Education (DHE) pada anak down syndrome yang tinggal di wilayah lahan basah selama pandemic covid.

Tabel 1. Kegiatan dan hasil PKM yang telah dilaksanakan

\begin{tabular}{|c|c|}
\hline Pelaksanaan Program & $\begin{array}{l}\text { Hasil } \\
\text { Pelaksanaan } \\
\text { Program }\end{array}$ \\
\hline $\begin{array}{l}\text { Kegiatan diawali dengan } \\
\text { parent education mengenai } \\
\text { kesehatan gigi dan mulut } \\
\text { secara umum kepada orang } \\
\text { tua bersama anak dengan } \\
\text { kondisi down syndrome } \\
\text { secara webinar online. }\end{array}$ & $\begin{array}{l}\text { Program PKM } \\
\text { dapat diterima } \\
\text { dan dapat } \\
\text { dilaksanakan } \\
\text { dengan baik } \\
\text { oleh tim FKG } \\
\text { ULM bersama } \\
\text { orang tua yang } \\
\text { memiliki anak } \\
\text { down syndrome. }\end{array}$ \\
\hline $\begin{array}{l}\text { Memberikan contoh demo } \\
\text { menggosok gigi yang benar } \\
\text { dengan menggunakan } \\
\text { pantom/model gigi dan } \\
\text { memberikan contoh } \\
\text { beberapa posisi menggosok } \\
\text { gigi bagi anak } \\
\text { berkebutuhan khusus } \\
\text { melalui webinar online. }\end{array}$ & $\begin{array}{l}\text { Sebanyak } 38 \\
\text { orang tua dapat } \\
\text { mengikuti } \\
\text { materi mengenai } \\
\text { persiapan dalam } \\
\text { menggosok gigi } \\
\text { diantaranya: } \\
\text { pemilihan sikat } \\
\text { gigi, } \\
\text { penggunaan } \\
\text { pasta gigi } \\
\text { sebagai } \\
\text { pencegahan } \\
\end{array}$ \\
\hline
\end{tabular}

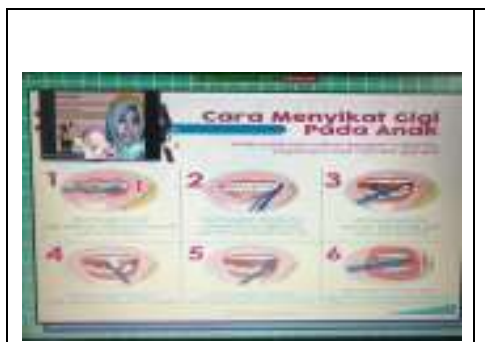

penuaran covid, cara menggosok gigi dengan benar, penggunaan obat kumur bukan dengan air lahan basah salah satunya air

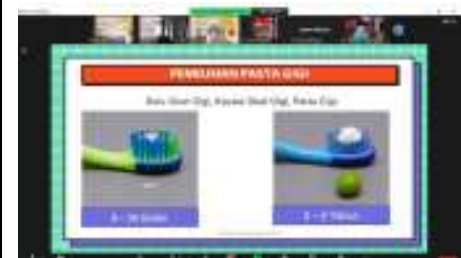
sungai, serta memahami posisi cara menggosok gigi bagi anak down syndrome maupun bagi anak

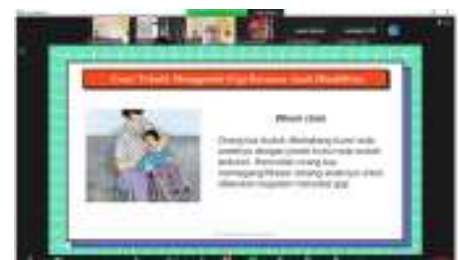
berkebutuhan khusus bersama tim PKM FKG ULM yang dilaksanakan secara bertahap.

Diskusi dan tanya jawab mengenai materi Dental Health Education (DHE) Antusias orang tua terhadap yang sudah diberikan education kepada orang tua bersama mengenai tim PKM FKG ULM.

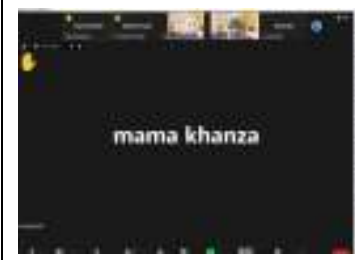

Dental Health Education (DHE) bagi anak down syndrome yang tinggal di wilayah lahan basah dalam pencegahan karies gigi

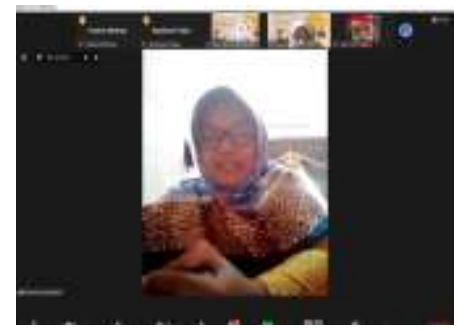
dengan bergantian mengajukan pertanyaan kepada tim PKM FKG ULM terkait Kesehatan gigi 


\begin{tabular}{|c|c|}
\hline & $\begin{array}{l}\text { dan mulut anak } \\
\text { mereka. }\end{array}$ \\
\hline $\begin{array}{l}\text { Pemutaran Video Dental } \\
\text { Health Education (DHE) } \\
\text { bagi anak down syndrome } \\
\text { yang tinggal di lahan basah } \\
\text { dalam pencegahan karies } \\
\text { gigi selama pandemi covid. }\end{array}$ & $\begin{array}{l}\text { Pemantapan } \\
\text { pemahaman } \\
\text { orang tua yang } \\
\text { berkenaan } \\
\text { dengan parent } \\
\text { education } \\
\text { kepada orang } \\
\text { tua anak down } \\
\text { syndrome } \\
\text { melalui video } \\
\text { DHE. }\end{array}$ \\
\hline $\begin{array}{l}\text { Penjelasan kepada orang } \\
\text { tua mengenai pengisian } \\
\text { google form yang berisi } \\
\text { cara menjaga Kesehatan } \\
\text { gigi dan mulut anak sebagai } \\
\text { pemantaban parent } \\
\text { education yang sudah } \\
\text { diberikan oleh tim PKM } \\
\text { FKG ULM setelah peberian } \\
\text { materi dan Video DHE } \\
\text { Bagi Anak Down syndrome } \\
\text { Sedang Yang Tinggal Di } \\
\text { Lahan Basah Dalam } \\
\text { Pencegahan Karies Gigi } \\
\text { Selama Pandemi Covid. }\end{array}$ & $\begin{array}{l}\text { Perekapan hasil } \\
\text { pengisian } \\
\text { google form } \\
\text { yang sudah diisi } \\
\text { akan diambil } \\
\text { kesimpulan } \\
\text { terhadap parent } \\
\text { education } \\
\text { program } \\
\text { menggunakan } \\
\text { video DHE } \\
\text { terhadap } \\
\text { pencegahan } \\
\text { karies gigi anak } \\
\text { yang tinggal di } \\
\text { lahan basah } \\
\text { selama pandemi } \\
\text { covid. }\end{array}$ \\
\hline
\end{tabular}

\section{Sub Bab 2}

Pelaksanaan PKM, selain dilaksanakan kegiatan penyuluhan mengenai parent education program pada orang tua anak down syndrome, juga dilaksanakan penelitian untuk mengetahu tingkat pengetahuan orang tua yang sudah diberikan materi parent education program menggunakan video DHE bagi anak down syndrome yang tinggal di lahan basah dalam pencegahan karies gigi selama pandemi covid.

Pengambilan sampel dilakukan dengan cara pengisian kuesioner melalui google form kepada orang tua yaitu sebanyak 38 responden untuk mengetahui tingkat pengetahuan orang tua terhadap kesehatan gigi dan mulut anak melalui video DHE dengan menentukan skor penilaian baik, cukup dan kurang, kemudian hasil kuesioner yang sudah terisi di hitung dan deskripsikan.

Menurut Teori Arikunto (2006). Kategori tingkat pengetahuan terdiri dari kurang, cukup dan baik. Pada penelitian PKM ini didapatkan kategori kurang terdiri dari 17 orang, kategori cukup terdiri dari 7 orang dan kategori baik terdiri dari 6 orang.

Tabel 2. Distribusi Tingkat Pengetahuan orang tua yang mendapat parent education program

\begin{tabular}{|c|l|l|l|}
\hline No. & Pengetahuan & \multicolumn{1}{|c|}{ N } & \multicolumn{1}{c|}{$\%$} \\
\hline 1 & Kurang & 2 & $5,3 \%$ \\
\hline 2 & Cukup & 4 & $10,5 \%$ \\
\hline 3 & Baik & 32 & $84,2 \%$ \\
\hline \multicolumn{2}{|c|}{ Jumlah } & 38 & $100 \%$ \\
\hline
\end{tabular}

Ket : $\mathrm{n}$ : Jumlah orang tua yang mengisi kuesioner melalui google form.

Tabel 2 diatas menunjukkan hasil tingkat pengetahuan terbanyak adalah dengan kategori baik sebanyak 32 orang dari 38 orang. Hasil tingkat pengetahuan paling sedikit adalah dengan tingkat pengetahuan dengan kategori kurang dengan jumlah sebanyak 2 orang. 


\section{TINGKAT PENGETAHUAN}

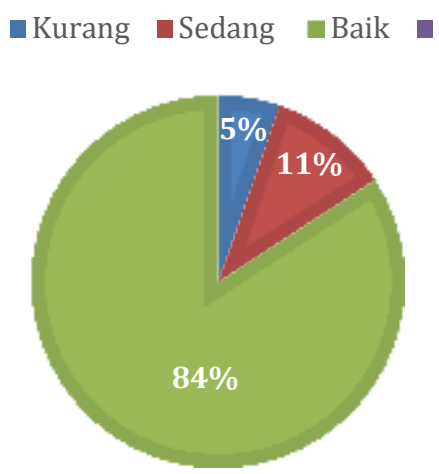

Diagram 1. Diagram Tingkat Pengetahuan ibu/pengasuh.

Diagram di atas menunjukkan persentase tingkatan pengetahuan berdasarkan Teori Arikunto. Kategori baik $84,2 \%$, kategori cukup sebanyak $10,5 \%$, dan kategori kurang sebanyak 5,3\%. Berdasarkan diagram tersebut, didapatkan hasil persentase tertinggi adalah pada tingkat pengetahuan dengan kategori baik yaitu sebesar 84,2\%.

Orang tua memiliki tanggung jawab terhadap kesehatan anggota keluarganya terutama anak. Orang tua harus memiliki pengetahuan yang cukup tentang kesehatan gigi dan mulut. Pengetahuan orang tua tentang kesehatan gigi merupakan hal yang penting dalam menunjang perilaku kesehatan gigi anak. Sehingga edukasi akan kesehatan rongga mulut kepada orang tua memainkan peran yang penting untuk menjaga kesehatan rongga mulut anak, terutama bagi anak down syndrome (Yulianti, 2011; Jyoti, 2019).

Anak down syndrome mempunyai kesulitan untuk merawat dirinya sendiri dan ketergantungan pada orang lain untuk manajemen perawatan diri. Permasalahan kesehatan rongga mulut pada anak down syndrome sangat memerlukan adanya bimbingan dari orang tua. Edukasi tentang kesehatan gigi dan mulut kepada orang tua merupakan faktor yang sangat penting dalam menjaga kesehatan rongga mulut anak (Shanbagh,2014; Atyanta, 2015).

Pendidikan kesehatan gigi dan mulut merupakan suatu proses pendidikan yang timbul atas dasar kebutuhan kesehatan gigi dan mulut yang bertujuan untuk menghasilkan kesehatan gigi dan mulut yang baik dan meningkatkan taraf hidup (Ali, 2016).

Beberapa faktor yang mempengaruhi pengetahuan orang tua terhadap kesehatan gigi. Pertama adalah tingkat pendidikan orang tua. Ketika seseorang berada pada tingkat pengetahuan yang lebih tinggi maka perhatian akan kesehatan gigi akan semakin baik. Begitu pula sebaliknya ketika seseorang memiliki pengetahuan yang kurang, maka perhatian akan perawatan gigi juga rendah. Hal-hal tersebutlah yang mendukung faktor pendidikan orang tua berpengaruh terhadap tingkat pengetahuan kesehatan gigi. (Christiono,2015; Purwati, 2017).

Orang tua merupakan salah satu unsur terpenting dalam perkembangan kesehatan khususnya kesehatan gigi dan mulut. Peran serta orang tua dalam menunjang program program pelayanan kesehatan gigi dan mulut bagi anakanak dapat berpengaruh pada peningkatan derajat kesehatan gigi dan mulut anak. Seorang anak adalah cerminan dari orang tua. Jadi peran orang tua sangat penting dalam proses pendidikan anak, bagaimana orang tua menjadi contoh yang baik, membimbing, mengarahkan dan memberikan motivasi. Apabila orang tua berperan maka anak akan mengerti dan mengamati kemudian anak dapat meniru apa yang dilakukan atau diajarkan oleh orang tua mereka. Orang tua harus mengetahui cara merawat gigi anaknya tersebut, dan orang tua juga harus mengajari anaknya cara merawat gigi yang baik. Peran orang tua dalam mengasuh, mendidik, dan mendorong, serta mengawasi anak dalam merawat kebersihan gigi penting untuk kesehatan anak (Prasuda, 2017; Manbait, 2019) 
Faktor selanjutnya

mempengaruhi yang terhadap kesehatan rongoa mulut adalah keadaan sosial ekonomi. Kebersihan rongga mulut lebih baik pada anak dengan status pekerjaan orang tua menengah keatas. Hal tersebut dikarenakan orang tua dari kalangan menengah ke atas menganggap penting pemeliharaan kesehatan gigi. Mereka mengharapkan kesehatan gigi yang optimal pada rongga mulut anak mereka. Hal tersebut sesuai dengan penelitian Christiono dan putranto 2015 yang menyatakan bahwa status karies yang buruk sebanyak $57,1 \%$ didukung oleh pendapatan orang tua yang hanya menghasilkan 1-2 juta perbulan sebanyak $47,6 \%$. Biaya perawatan gigi yang cukup mahal membuat orang tua jarang memeriksakan gigi ke dokter gigi dan enggan untuk melakukan perawatan preventif. Tindakan preventif kesehatan gigi yang sering diabaikan di masyarakat, sehingga membuat kegiatan yang dilakukan pada penelitian ini adalah melakukan pemberian tooth mousse untuk anak di desa Sugara (Christiono dan Putranto,2015: Ngantung dkk,2015: Purwati dan Almujadi, 2017).

Umur orang tua atau ibu juga merupakan faktor yang penting terhadap kesehatan rongga mulut anaknya. Hal tersebut dikarenakan umur merupakan salah satu faktor yang dapat menentukan kematangan seseorang baik dalam berfikir, bertindak, maupun belajar. Kematangan dalam berfikir seseorang yang dapat memepengaruhi baik pengetahuan, sikap, maupun praktek seseorang. Semakin bertambah usia akan semakin berkembang pula daya tangkap dan pola pikirnya. Sehingga pengetahuan yang diperoleh semakin membaik (Christiono dan Putranto,2015: Ngantung dkk,2015; Purwati dan Almujadi, 2017).

Dampak dari program pelaksanaan PKM CSR ini adalah meningkatkan pengetahuan mitra sasaran yaitu masyarakat yang tinggal di Desa Pulau Sugara terhadap pencegahan karies yang dilakukan dengan memberikan penyuluhan terutama kepada $\mathrm{ibu} /$ pengasuh dan anak. Informasi yang dapat diberikan kepada orang tua atau ibu adalah membersihkan gigi anak mulai dari gigi sudah erupsi, jangan membiarkan anak tertidur sambil minum melalui botol yang berisi susu formula atau jus buah atau larutan yang manis, membangun kebiasaan anak untuk selalu menyikat gigi minimal 2 kali sehari, menyikat gigi sebelum tidur, dan mulai berkunjung ke dokter gigi sejak tahun pertama kelahiran secara teratur.

\section{KESIMPULAN}

Kegiatan pengabdian yang telah dilakukan oleh tim PKM FKG ULM melalui penyuluhan parent education program dengan menggunakan video DHE kepada orang tua anak down syndrome telah berjalan dengan lancar serta mendapatkan respon yang sangat positif oleh ketua dan anggota yayasan PIK POTADS Kalimantan Selatan.

Hasil pengabdian yang telah dilakukan, sebagian besar pengetahuan dan pemahaman setelah penyuluhan kepada orang tua anak down syndrome dalam parent education program menggunakan video animasi Dental Health Education (DHE) bagi anak down syndrome dalam pencegahan karies gigi selama pandemi covid termasuk dalam kategori baik 84,2\% yakni sebanyak 32 orang, sehingga dapat disimpulkan bahwa penyuluhan ini dapat mengetahui dan meningkatkan pengetahuan orang tua anak down syndrome dalam menjaga Kesehatan dan kebersihan rongga mulutnya.

\section{UCAPAN TERIMAKASIH}

Terima kasih kepada Fakultas Kedokteran Gigi, Yayasan PIK POTADS Kalimantan Selatan.

\section{REFERENSI}

Hafsah, A. Penyakit Sindrom Down (Down Syndrome). (2020). Makalah Biologi. 
Chrisly E. N. D. Rampi, C.E.N.D., Gunawan, P., Pangemanan, D.H.C. (2017). Gambaran Kebersihan Gigi Dan Mulut Pada Anak Penderita Down Syndrome Di Slb Ypac Manado. Jurnal KEDOKTERAN KLINIK (JKK), Volume 1 No 3.

Soewondo, W. (2019). Pendidikan Kesehatan Gigi Untuk Penyandang Sindrom Down. Jurnal Pengabdian kepada Masyarakat. Vol. 4, No. 3: 55 - 58.

Ozkan Ozgul, Erhan Dursun, Betul Memis Ozgul, Yasemin Kartal, Fatih Mehmet Coskunses, Ismail Doruk Kocyigit, Tolga F Tözüm. (2015). The Impact of Handicap Severity on Oral and Periodontal Status of Patients with Mental Retardation. JCDP: 10.5005/jp-journals-10024-1518

Monica M. Sengkey, Damajanty H. C. (2015). Pangemanan, Christy N. Mintjelungan. Status Kebersihan Gigi dan Mulut pada Anak Autis di Kota Manado. Jurnal e- GiGi (eG). p; 3(2): 235-240.

Kementrian kesehatan Indonesia (Kemenkes). (2020). Pedoman Umum menghadapai pandemic Covid-19. Kementrian Kesehatan Indonesia. p:146148.

Andriyani, I.P. (2017). Pengembangan Video Pembelajaran Pada Program Bina Diri Menggosok Gigi Untuk Siswa Tunagrahita Kelas Iii Di Sekolah Pendidikan Khusus Negeri Karanganyar Kebumen. UNS: P. 20-25.

Novitasari. (2016). Pengaruh penggunaan multimedia interaktif terhadap kemampuan pemahaman konsep matematis siswa. Jurnal Pendidikan matematika. Vol. 2 No. 2

Kantohe ZR. (2016). Perbandingan efektivitas pendidikan kesehatan gigi menggunakan media video dan flip chart terhadap peningkatan pengetahuan kesehatan gigi dan mulut anak. Jurnal E-gigi. 4(2): 96-101

Sujarwati, F.P., Utami, R.D.P., Rizqiea, N.S. (2019). Pengaruh Parent Education Program Terhadap Kemampuan Menggosok Gigi Anak Tunagrahitadi Slb Negeri Sragen. Diunduh dari: https://eprints.ukh.ac.id/id/eprint/511/1/Naskah\%2 Opublikasi\%20Fitri\%20Poniasih\%20Sujarwati.pdf.

Arikunto. (2006). Prosedur Penelitian Suatu Pendekatan Praktek. Jakarta: PT. Rineka Cipta.

Yulianti RP. Muhlisin A. (2011). Hubungan Antara Pengetahuan Orang Tua Tentang Kesehatan Gigi Dan Mulut Dengan Kejadian Karies Gigi Pada Anak Di Sdn V Jaten Karanganyar. Jurnal Terbitan Berkala Ilmiah. 4(1): 25-34

Jyoti NPCP, Giri PRK, Handoko SA, Kurniati DPY, Rahaswanti LWA. (2019). Hubungan tingkat pengetahuan dan perilaku ibu dalam merawat gigi anak terhadap kejadian karies anak di TK Titi Dharma Denpasar. Bali Dental Journal. 3(2):96-102.

Shanbhag PP, Ram SM, Gupta B. (2014). Knowledge and oral health attitudes among care providers of children with intellectual disabilities: A cross-sectional study. J Contemp Dent. 4 (2): 92-8.

Atyanta A, Hanum F, Amurwaningsih M. (2015). Hubungan tentang tingkat pengetahuan ibu tentang karies dan peran ibu dalam mencegah karies pada anak tunagrahita. Medali J. 2 (1): 4852.

Ali RA, Wowor VNS, Mintjelungan. (2016). Efektivitas Dental Health Education Disertai Demonstrasi Cara Menyikat Gigi Terhadap Tingkat Kebersihan Gigi Dan Mulut Anak Sekolah Dasar. Pharmacon Jurnal Ilmiah Farmasi. 5(1); 164-172.

Christiono S, Putranto R. (2015). Caries Status Early Childhood Caries in Indonesian Children with Special Needs: Study in SDLB Central Java. Odonto Dental Journal. 2(2):1-7. 
Purwati DE, Almujadi. (2017).

Pengaruh Tingkat Pendidikan Dan Pekerjaan

Orang Tua Terhadap Jumlah Karies Gigi

Siswaanak Sekolah Dasar. Jurnal Kesehatan

Gigi. 4(2): 33-39.

Prasuda. (2017). Peningkatan

Pendidikan Orang Tua Sebagai Strategi

Penanganan Karies Gigi Anak Usia 7 - 9

Tahun. Nursing news. 3(2): 813-822.

Manbait MR. (2019). Peran Orang Tua dalam Pemeliharaan Kesehatan Gigi dan Mulut. Dental Therapist Journal. 1(2);74-79.

Ngantung RA., Damajanty H. C. Pangemanan, Gunawan P. (2015). Pengaruh Tingkat Sosial Ekonomi Orang Tua terhadap Karies. Anak di TK Hang Tuah Bitung. Jurnal e-GiGi. 3(2):10-14. 